\title{
SIMULTANEOUS DETERMINATION OF EMTRICITABINE AND TENOFOVIR BY AREA UNDER CURVE AND DUAL WAVELENGTH SPECTROPHOTOMETRIC METHOD
}

\author{
SWAPNIL A GHORPADE, MONALI S. SALI, ATUL H. KATEGAONKAR, DHAVAL M. PATEL, \\ VISHNU P CHOUDHARI*, BHANUDAS S KUCHEKAR
}

MAEER'S Maharashtra Institute of Pharmacy, S.No. 124, MIT Campus, Paud Road, Kothrud, Pune-411038, MS, India.

(Received: May 26, 2009 - Accepted: January 24, 2010)

\begin{abstract}
Two methods for the simultaneous determination of Emtricitabine and Tenofovir by spectroscopy have been developed. These two simple, accurate and precise methods include Area Under the Curve (AUC) method and Dual Wavelength Method. From a solvent effect studies and the spectral behaviours of Emtricitabine and Tenofovir, methanol was selected as solvent. Emtricitabine shows maximum absorbance at $281 \mathrm{~nm}$ and Tenofovir shows maximum absorbance at $259 \mathrm{~nm}$. For the AUC method, the wavelength ranges between $242-248 \mathrm{~nm}$ and $269-275 \mathrm{~nm}$ were selected with reference to the absorbance curves plotted between the wavelengths of 200-400 nm. In the second method i.e. Dual method in which two wavelengths were selected for each drug in a way so that the difference in absorbance is zero for another drug. Emtricitabine shows equal absorbance at $230.696 \mathrm{~nm}$ and $250 \mathrm{~nm}$, where the differences in absorbance were measured for the determination of Tenofovir. Similarly, differences in absorbances at $250 \mathrm{~nm}$ and $268.670 \mathrm{~nm}$ were measured for determination of Emtricitabine. These methods allows rapid analysis of two drug combination. The results of analysis were validated statistically and by recovery studies. This tablet containing both drugs was assayed using the methods developed, showing a good accuracy and precision.
\end{abstract}

Keywords: Spectroscopy; Emtricitabine; Tenofovir; Area Under Curve Method ; Dual Wavelength; Pharmaceutical Formulation.

\section{INTRODUCTION}

Tenofovir (TE; 9-[(R)-2-[[bis[[(isopropoxycarbonyl) oxy] methoxy] phosphinyl] methoxy] propyl) and Emtricitabine (EM; 5-fluro-1-(2R, 5S)-[29hydroxymethyl]- 1,3-oxathiolan-5-y, Figure 1) both are the antiviral agents. Acts as the Nucleoside Reverse Transcriptase enzyme Inhibitors. These are the Nucleoside analogues which are phosphorylated by host cell enzyme to give 5 -triphosphate derivative. This moiety competes with the equivalent host cellular triphosphate substrates for proviral DNA synthesis by viral reverse transcriptase which is viral RNA-dependent DNA polymerase. Eventually, the incorporation of the 5-triphosphate moiety into the growing viral DNA chain results in chain termination. Mammalian $\alpha$-DNA polymerase is relatively resistant to the effect. EM is potent and selective against HIV types I and II and hepatitis B virus. TE is active against a variety of drug resistant HIV-I strains. Recently, the combination of EM and TE has demonstrated significantly greater HIV RNA suppression compared to the combination of zidovudine and lamivudine $e^{1-3}$
Emtricitabine

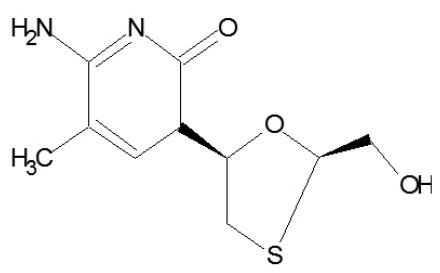

Tenofovir

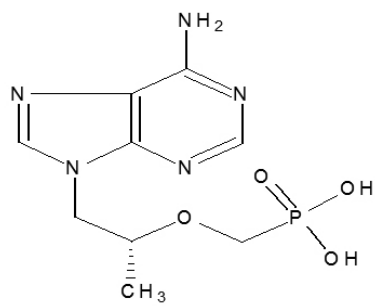

Fig. 1. The structures of Emtricitabine and Tenofovir.

Several analytical methods that have been reported for the individual determination of TE in biological fluids and pharmaceutical formulations which include liquid chromatography coupled with spectrofluorimetric, UV, and mass spectroscopy detection ${ }^{4-10}$. For EM several analytical methods have been reported for its individual analysis which includes chiral liquid chromatography, liquid chromatography with UV detection ${ }^{11-13}$. Few Bioanalytical methods are reported for combination of TE and EM which includes liquid chromatography with PDA and UV detection ${ }^{14,15}$. There is no spectroscopic method available in the literature for the simultaneous estimation of EM and TE in combined dosage form. The aim of this study was to develop and validate simple, rapid, selective and low cost Area under Curve and Dual Wavelength Spectrophotometer Methods for the determination of TE and EM in tablet dosage. The proposed method was optimized and validated as per the International Conference on Harmonization (ICH) guidelines ${ }^{16}$.

\section{EXPERIMENTAL:}

\section{Instruments}

An UV-Visible double beam spectrophotometer (Varian Cary 100) with $10 \mathrm{~mm}$ matched quartz cells were used for spectrophotometric methods. All weighing were done on electronic balance (ModelShimadzu AUW-220D).

\section{MATERIALS AND METHODS}

\section{Reagents :}

Spectroscopy grade methanol was used throughout the study. Pure drug sample of TE, \% purity 99.86 and EM, \% purity 99.82 were kindly supplied as a gift sample by Emcure Pharmaceuticals Pvt. Ltd. Pune, India. It was used without further purification. Tablets were purchased from local market, each containing Tenofovir disoproxil fumarate $300 \mathrm{mg}$ and Emtricitabine $200 \mathrm{mg}$. Tablet used for analysis were TENVIR-EM (Batch No. X81241) manufactured by Cipla Ltd., Goa.

Preparation of standard Stock Solutions and Sample solution:

Standard stock solution of $1000 \mu \mathrm{g} / \mathrm{mL}$ of both the drugs was prepared separately in methanol. For verification of Beer's Law, a series of diluted solutions of Tenofovir and Emtricitabine ranging from 6-48 $\mu \mathrm{g} / \mathrm{mL}$ (series A) and 4-32 $\mu \mathrm{g} / \mathrm{mL}$ (series B), respectively were prepared and mixture of both the drugs in (series C) of same concentration range were prepared in methanol. ${ }^{17}$

For preparation of sample stock solution, twenty tablets were weighed accurately and a quantity of tablet powder equivalent to $100 \mathrm{mg}$ of TE (66.66 $\mathrm{mg}$ of EM) was weighed and dissolved in the $80 \mathrm{~mL}$ of methanol with the aid of ultrasonication for $5 \mathrm{~min}$ and solution was filtered through Whatman filter paper No. 41 into a $100 \mathrm{~mL}$ volumetric flask. Filter paper was washed with methanol, adding washings to the volumetric flask and volume was made up to the mark with methanol. The sample stock solution was suitably diluted further to get required final concentration of TE $(24 \mu \mathrm{g} / \mathrm{mL})$ and $\mathrm{EM}(16 \mu \mathrm{g}$ $/ \mathrm{mL}$ ).

\section{METHODS}

Method A: AREA UNDER CURVE METHOD

For the simultaneous determination using the area under the curve method, suitable dilutions of the standard stock solutions $(1000 \mu \mathrm{g} / \mathrm{ml})$ of TE and EM were prepared separately. The solution of drugs were scanned in the range of $200-400 \mathrm{~nm}$. For Area Under Curve method, the sampling wavelength ranges selected for estimation of EM and TE are 242-248 nm $\left(\lambda_{1}-\lambda_{2}\right)$ and $269-275 \mathrm{~nm}$ $\left(\lambda_{3}-\lambda_{4}\right)$. Mixed standard were prepared and their Area Under the Curve were measured at the selected wavelength ranges ${ }^{18,19}$. Concentration of two drugs in mixed standard and the sample solution were calculated using equation (1) and (2).
$\mathrm{A}_{1}=868.25 \mathrm{C}_{\mathrm{TE}}+1985 \mathrm{C}_{\mathrm{FM}}$
$\mathrm{A}_{2}=819.54 \mathrm{C}_{\mathrm{TE}}^{\mathrm{TE}}+1710.06 \mathrm{C}_{\mathrm{EM}}$
(1) at $242-248 \mathrm{~nm}$
(2) at $269-275 \mathrm{~nm}$

Where, 
868.25 And 819.54 are absortivities of TE at $\left(\lambda_{1}-\lambda_{2}\right)$ and $\left(\lambda_{3}-\lambda_{4}\right)$ respectively. 1985 and 1710.06 are absortivities of EM at $\left(\lambda_{1}-\lambda_{2}\right)$ and $\left(\lambda_{3}-\lambda_{4}\right)$ respectively.

$A_{1}$ and $A_{2}$ are absorbances of mixed standard at $\left(\lambda_{1}-\lambda_{2}\right)$ and $\left(\lambda_{3}-\lambda_{4}\right)$ respectively. $\mathrm{C}_{\mathrm{TE}}$ and $\mathrm{C}_{\mathrm{EM}}$ are the concentrations in $\mathrm{g} / 100 \mathrm{~mL}$.

\section{Method B: DUAL WAVELENGTH METHOD}

The spectrum of TE Figure 2 show that absorbance of TE is identical at $250 \mathrm{~nm}(\lambda 1)$ and $268.679 \mathrm{~nm}(\lambda 2)$ therefore these two wavelength were selected for the analysis of EM. All the solutions of series $\mathbf{A}$ were scanned to ensure that the difference of absorbance between $\lambda_{1}$ and $\lambda_{2}$ is zero. Similarly, the EM solutions were scanned to determine the two wavelengths, where absorbance is same. These two wavelengths were found to be $230.696 \mathrm{~nm}\left(\lambda_{3}\right)$ and 250 $\mathrm{nm}\left(\lambda_{4}\right)$. All the solution of series B were scanned to ensure that difference of absorbance between $\left(\lambda_{3}\right)$ and $\left(\lambda_{4}\right)$ is zero. Thereafter, the solution of series $\mathbf{C}$ were scanned to ensure that varying concentration of TE and EM are not affecting the absorbance at selected wavelength. Difference in absorbances between $250 \mathrm{~nm}(\lambda 1)$ and $268.679 \mathrm{~nm}(\lambda 2)$ of series C solutions was used for preparation of calibration curve for EM. Similarly difference in absorbance between $230.696 \mathrm{~nm}\left(\lambda_{3}\right)$ and $250 \mathrm{~nm}\left(\lambda_{4}\right)$ of mixed standard solutions was used for preparation of calibration curve for TE.

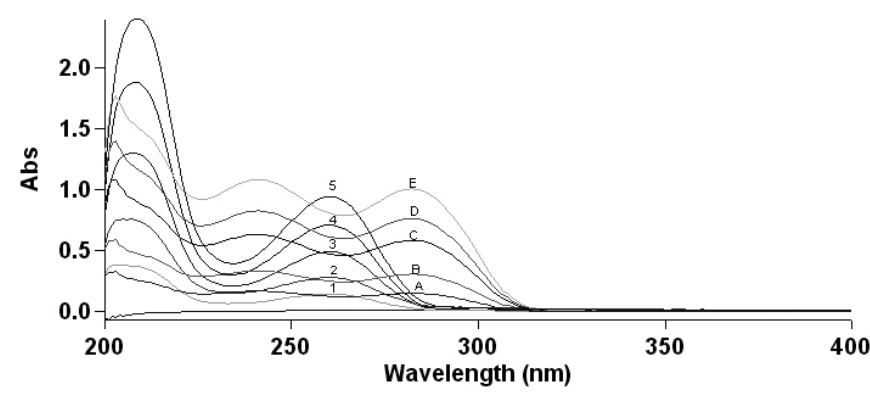

Fig. (2). Overlain spectra of Tenofovir in methanol: (1) $6 \mu \mathrm{g} / \mathrm{mL}$; (2) 12 $\mu \mathrm{g} / \mathrm{mL}$; (3) $24 \mu \mathrm{g} / \mathrm{mL}$; (4) $36 \mu \mathrm{g} / \mathrm{mL}$; (5) $48 \mu \mathrm{g} / \mathrm{mL}$ and Emtricitabin (A) $4 \mu \mathrm{g} /$ $\mathrm{mL}$; (B) $8 \mu \mathrm{g} / \mathrm{mL}$; (C) $16 \mu \mathrm{g} / \mathrm{mL}$; (D) $24 \mu \mathrm{g} / \mathrm{mL}$; (E) $32 \mu \mathrm{g} / \mathrm{mL}$.

\section{RESULTS AND DISCUSSION}

\section{RECOVERY METHOD}

The accuracy of the proposed method was checked by recovery studies, by addition of standard drug solution to preanalysed sample solution at three different concentration levels $(50 \%, 100 \%$ and $150 \%)$ within the range of linearity for both the drugs. The basic concentration level of sample solution selected for spiking of the drugs standard solution was $12 \mu \mathrm{g} / \mathrm{mL}$ of TE and 8 $\mu \mathrm{g} / \mathrm{mL}$ of EM. Results of the recovery are presented in Table 1 and 2.

\begin{tabular}{|c|c|c|c|c|c|c|c|c|}
\hline \multicolumn{2}{|c|}{ Table 1 : Recovery study of Tenofovir and Emtricitabine for Method A } \\
\hline $\begin{array}{c}\text { Level of } \% \\
\text { Recovery }\end{array}$ & \multicolumn{2}{|c|}{$\begin{array}{c}\text { Amount Spiked } \\
(\mu \mathrm{g} / \mathrm{mL})\end{array}$} & \multicolumn{2}{c|}{$\begin{array}{c}\text { Amount recovered } \\
(\mu \mathrm{g} / \mathrm{mL})\end{array}$} & \multicolumn{2}{c|}{$\begin{array}{c}\% \text { Mean } \\
\text { recovery }\end{array}$} & \multicolumn{2}{c|}{ Relative standard deviation \% (R.S.D., n= 6) } \\
\hline & $\mathrm{TE}$ & $\mathrm{EM}$ & $\mathrm{TE}$ & $\mathrm{EM}$ & $\mathrm{TE}$ & $\mathrm{EM}$ & TE & EM \\
\hline 50 & 6.06 & 4.04 & 6.08 & 3.98 & 100.33 & 98.51 & 0.53 & 0.52 \\
\hline 100 & 12.12 & 8.08 & 11.97 & 8.09 & 98.76 & 100.12 & 1.92 & 0.79 \\
\hline 150 & 18.18 & 12.12 & 18.10 & 12.13 & 99.55 & 100.08 & 1.04 & 0.21 \\
\hline
\end{tabular}

Table 2 : Recovery study of Tenofovir and Emtricitabine by Method B

\begin{tabular}{|c|c|c|c|c|c|c|c|c|}
\hline $\begin{array}{c}\text { Level of } \\
\% \text { Recovery }\end{array}$ & \multicolumn{2}{|c|}{$\begin{array}{c}\text { Amount Spiked } \\
(\mu \mathrm{g} / \mathrm{mL})\end{array}$} & \multicolumn{2}{c|}{$\begin{array}{c}\text { Amount. recovered } \\
(\mu \mathrm{g} / \mathrm{mL})\end{array}$} & \multicolumn{2}{c|}{$\begin{array}{c}\text { \% Mean } \\
\text { Recovery }\end{array}$} & \multicolumn{2}{c|}{$\begin{array}{c}\text { Relative standard deviation } \% \\
(\text { R.S.D., } \mathrm{n}=6)\end{array}$} \\
\hline & $\mathrm{TE}$ & $\mathrm{EM}$ & $\mathrm{TE}$ & $\mathrm{EM}$ & $\mathrm{TE}$ & $\mathrm{EM}$ & $\mathrm{TE}$ & $\mathrm{EM}$ \\
\hline 50 & 6.08 & 4.05 & 6.10 & 4.03 & 100.32 & 99.50 & 0.96 & 0.97 \\
\hline 100 & 12.09 & 8.06 & 12.14 & 8.04 & 100.43 & 100.37 & 0.89 & 0.38 \\
\hline 150 & 17.96 & 11.97 & 17.94 & 12.12 & 99.88 & 101.25 & 0.72 & $0 . .51$ \\
\hline
\end{tabular}

\section{Analytical features:}

Simple, precise and accurate Area under curve and Dual wavelength methods were developed for the simultaneous estimation of tenofovir and emtricitabine in combined dosage form. Optical characteristics and statistical data for the proposed method in table 3.

For METHOD A Beer's law obeyed in the concentration range 6-48 $\mu \mathrm{g} /$ $\mathrm{mL}$ and $4-32 \mu \mathrm{g} / \mathrm{mL}$ TE and EM, respectively. Results of recovery studies are shown in Table 2. For TE, the recovery study results ranged from $99.01 \%$ to $101.46 \%$ with $\%$ RSD values ranging from $0.52 \%$ to $1.72 \%$. For EM the recovery results ranged from $99.06 \%$ to $99.96 \%$, with \% RSD values ranging from $0.5 \%$ to $0.99 \%$. The accuracy and reproducibility is evident from the data as results are close to $100 \%$ and standard deviation is low.

For METHOD B Beer's law obeyed in the concentration range 6-48 $\mu \mathrm{g} / \mathrm{mL}$ and $4-32 \mu \mathrm{g} / \mathrm{mL}$ TE and EM, respectively. Results of recovery studies for Dual Wavelength Method are shown in Table 3. For TE, the recovery study results ranged from $99.69 \%$ to $101.48 \%$ with $\%$ RSD values ranging from $0.89 \%$ to $0.96 \%$. For EM the recovery results ranged from $99.15 \%$ to $101.45 \%$, with $\%$ RSD values ranging from $0.51 \%$ to $1.38 \%$. The accuracy and reproducibility is evident from the data as results are close to $100 \%$ and standard deviation is low

\section{PRECISION}

To study intraday precision method was repeated 5 times in a day and average \% RSD was found to be 1.16 and $0.59 ; 0.34$ and 0.18 for TE and EM respectively, for method A and B respectively. Similarly to study interday precision, the method was repeated on five different days and the average \% RSD was found to be 1.16 and $0.59 ; 0.34$ and 0.18 for TE and EM respectively, for method A and B, respectively. These values confirm the intra and inter day precision. 


\begin{tabular}{|c|c|c|c|c|c|}
\hline \multirow{2}{*}{\multicolumn{2}{|c|}{ Parameter }} & \multicolumn{2}{|c|}{ Tenofovir } & \multicolumn{2}{|c|}{ Emtricitabine } \\
\hline & & METHOD A & METHOD B & METHOD A & METHOD B \\
\hline \multirow{2}{*}{$\begin{array}{l}\text { Regression Equation }(\mathrm{y}= \\
\mathrm{mx}+\mathrm{c})\end{array}$} & Intercept (c) & - & 0.00904 & - & 0.00369 \\
\hline & Slope (m) & - & 0.002 & - & -0.0007 \\
\hline \multicolumn{2}{|c|}{ Correlation Coefficient } & - & 0.9982 & - & 0.9903 \\
\hline Precision & Interday & 1.09 & 0.98 & 1.40 & 1.19 \\
\hline
\end{tabular}

\section{FORMULATION ANALYSIS:}

The proposed methods were used for analysis of the marketed tablet formulation as described in Instruments and reagents section. Drugs were extracted from the formulation as described in Preparation of Stock and Sample solutions section and subjected to the proposed methods, overlain spectrum of standard mixture and formulation are shown in figure(3) and results of formulation analysis are presented in Table 4.

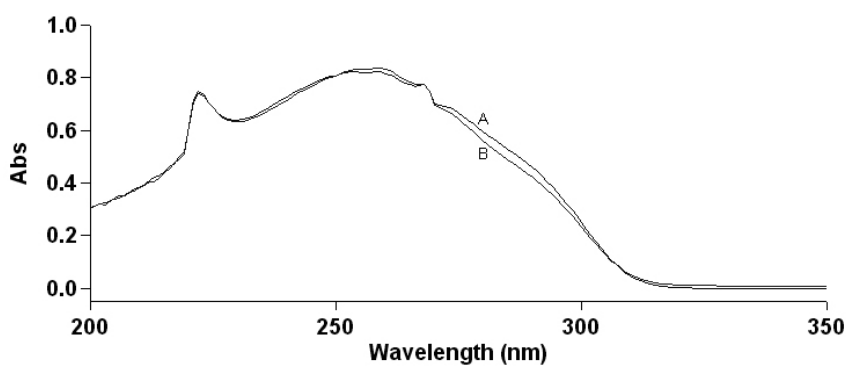

Fig (3). Overlain Spectra of A :-Std. mixture of TE. $(24 \mu \mathrm{g} / \mathrm{mL})$ and EM. $(16 \mu \mathrm{g} / \mathrm{mL})$ and B :-Sample mixture of TE. $(24 \mu \mathrm{g} / \mathrm{mL})$ and EM. $(16 \mu \mathrm{g} / \mathrm{mL})$.

\begin{tabular}{|c|l|c|c|c|}
\hline \multicolumn{2}{|c|}{ Table 4: Results of commercial formulation analysis } \\
\hline \multirow{2}{*}{ Method } & Drug & $\begin{array}{c}\text { Label } \\
\text { Claim (mg/ } \\
\text { tablet) }\end{array}$ & $\begin{array}{c}\text { \% of Label } \\
\text { Claim } \\
\text { Estimated }\end{array}$ & $\begin{array}{c}\% \\
\text { R.S.D. }\end{array}$ \\
\hline $\begin{array}{c}\text { Area Under } \\
\text { Curve Method }\end{array}$ & Tenofovir & 300 & 99.70 & 0.98 \\
\cline { 2 - 5 } $\begin{array}{c}\text { Dual } \\
\text { Wavelength } \\
\text { Method }\end{array}$ & Emtricitabine & 200 & 99.92 & 1.23 \\
\cline { 2 - 5 } & Eenofovir & 300 & 99.75 & 0.92 \\
\hline
\end{tabular}

\section{CONCLUSION}

The validated spectrophotometric method employed here proved to be simple, economical, precise and accurate. Thus it can be used as IPQC test and for routine simultaneous determination of TE and EM in tablet dosage form.

\section{ACKNOWLEDGEMENT}

The authors wish to express their gratitude to Emcure Pharmaceuticals Pvt. Ltd. Pune, India, for the sample of pure Tenofovir and Emtricitabine gift samples. The authors are also thankful to the management of MAEER's Maharashtra Institute of Pharmacy for providing necessary facilities.

\section{REFERENCES}

1. H.B. Fung, E.A. Stone, F.J. Piacenti, Clin. Ther. 24, 1515-1538 (2002).

2. M.S. Saag, P. Cahn, F. Raffi, Evid.-Based Healthcare Public Health 9, 75-764 (2005).

3. H.P.Rang, M.M.Dale, J.M.Ritter,R.J.Flower ,Rang And Dale's, Pharmacology, 6 th edn., Published by Churchill Livingstone, elsever pp 685.

4. V. Jullien, J Tre'luyer, G .Pons, E. Rey, J. Chromatogr. B 785, 377-381. (2003).

5. V. Bezy, P. Morin, P. Couerbe, G. Leleu, L Agrofoglio et.al, J Chromatogr. B 821, 132-143. (2005).

6. T. Delahunty, L Bushman, C .V Fletcher, et.al J Chromatogr. B 830 6-12. (2006).

7. M. E Barkil, M .Gagnieu, J. Guitton, et.al J Chromatogr. B 854, . 192197. (2007).

8. S. Sentenac, C. Fernandez, A. Thuillier, P et.al J Chromatogra. B.793 ,317-324. (2003).

9. R.W. Sparidens, K.M. Crommentuyn, J.H. Schellens, et.al, J.Chromatogr. B. 791,227 . (2003).

10. A Checaa, R Oliver, S Herna'ndez-Cassoua, J Saurina, A. chimica act. 61,685-94(2008).

11. Q B. Cass, C S.F. Watanabe, J. A. Rabi, P. Q. Bottari, M.R. Costa, R. M. Nascimento ,J. E.D. Cruz, R. C. Ronald, J. Pharm. Biomed. Anal.33 ,581-587(2003).

12. S. Notari, A. Bocedi, G. Ippolito, et.al, J Chromatogr. B, 831 ,258-266. (2006).

13. N.L. Rezk, R. D. Crutchley, A. D.M. Kashuba, et.al J. Chromatogr.B, 822 , 201-208. (2005).

14. Nirogi R, Bhyrapuneni G, Kandikere V, Mudigonda K, Biomed Chromatogr.,23(4), 371-81. (2009).

15. Noel A. Gomesa,Vikas V. Ashutosh Pudageb, Santosh J. Pharm. Biomed. Anal.48, 918-926. (2008) .

16. ICH-Q2B Validation of Analytical Procedures: Methodology International Conference on Harmonization of Technical Requirements for Registration of Pharmaceuticals for Human Use, Geneva, Switzerland, 1996.

17. N.Fernandes, M.S.Nimdeo, V.P.Choudhari et.al., Int.J.Chem.Sci,6(1),2935. (2008).

18. Asha Thomas, Sandip Bodkhe,Lata Kothapalli et.al, Asian Journal Of Chemistry, 19(5),3821-3830. (2007)

19. Thomas A.B.,Dumbre N.G., Nanda R.K. et.al., Indian Drugs,45(8), 643$648(2008)$ 